\title{
Effects of Increasing Levels of Defatted Rice Bran on Intestinal Physical Barrier and Bacteria in Finishing Pigs
}

\author{
Huan Wang 1,2, Pinghua Li 1,2,3,4,*, Taoran Du ${ }^{1,2}$, Guang Pu ${ }^{1,2}$, Lijuan Fan ${ }^{1,2}$, Chen Gao ${ }^{1,2}$, \\ Peipei Niu ${ }^{2}$, Chengwu Wu ${ }^{1,2}$, Wuduo Zhou ${ }^{1,3}$ and Ruihua Huang 1,2,3 (D) \\ 1 Institute of Swine Science, Nanjing Agricultural University, Nanjing 210095, China; \\ 2017105010@njau.edu.cn (H.W.); dtrnjau@163.com (T.D.); puguang940105@163.com (G.P.); \\ 18305177622@163.com (L.F.); GC1594140795@126.com (C.G.); W1692716569@126.com (C.W.); \\ zhouwuduo@163.com (W.Z.); rhhuang@njau.edu.cn (R.H.) \\ 2 Huaian Academy, Nanjing Agricultural University, Huaian 223003, China; niupeipei2@126.com \\ 3 Industrial Technology System Integration Innovation Center of Jiangsu Modern Agriculture (PIG), \\ Nanjing 210095, China \\ 4 Nanjing Agricultural University's New Rural Research and Development Corporation of Huaian City, \\ Huaian 223003, China \\ * Correspondence: lipinghua718@njau.edu.cn
}

Received: 8 November 2019; Accepted: 25 November 2019; Published: 28 November 2019

Simple Summary: In China, the largest pig-raising country in the world, feed resources are gradually scarce, and the imports of grain crops including corn are increasing. Therefore, it is an urgent problem to find alternatives to grain feed materials. Defatted rice bran (DFRB), an abundant and underutilized agricultural coproduct of brown rice refining process, is rich in energy and dietary fiber (DF). The aims of this study were to assess the effects of increasing levels of DFRB $(0 \%, 7 \%, 14 \%, 21 \%$, and $28 \%$ DFRB) as a replacement for corns on intestinal physical barrier function and numbers of specific bacteria, and determine the optimal substitution level of DFRB in finishing pigs. We found that $7 \%$ DFRB as a replacement for corns had a beneficial effect on intestinal wall thickness, Bifidobacterium and Clostridium perfringens (C. perfringens), and had no adverse effect on intestinal permeability and Escherichia coli.

\begin{abstract}
The aims of this study were to assess the effects of increasing levels of DFRB as a replacement for corns on intestinal physical barrier function and bacteria of finishing pigs. A total of 35 castrated finishing pigs (age: $158.5 \pm 2.0 \mathrm{~d}$, initial body weight: $62.9 \pm 0.8 \mathrm{~kg}$ ) were randomly divided into five dietary treatments (seven replicates/treatment) for a 28 -day experimental period, i.e., a control diet with basal diet, and four experimental diets in which maize was replaced by $7 \%, 14 \%, 21 \%$, and $28 \%$ DFRB, respectively. The results showed that serum endotoxins concentration and diamine oxidase (DAO) activity were both increased (linear, $p=0.0004,0.001$, respectively) with DFRB level. However, compared with control group, serum endotoxins concentration and DAO activity were not different in pigs fed with $7 \%$ DFRB in the diet. There was a quadratic response in serum D-lactate concentration to the increased DFRB (quadratic, $p=0.021$ ). In the cecum, thickness of the intestinal wall significantly increased with increasing levels of DFRB in the diets (linear, $p=0.033$ ), while crypt depth/thickness of the intestinal wall ratio significantly decreased with increasing level of DFRB in the diets (linear, $p=0.043$ ). In the jejunum, total bacteria, Escherichia coli, and Bifidobacterium all responded quadratically to increasing levels of DFRB in the diets (quadratic, $p=0.003,0.001,0.006$, respectively). Additionally, there was no difference in Escherichia coli in pigs fed 0\%,7\%, and 14\% DFRB diets. In the colon, there were quadratic responses in C. perfringens to the increased DFRB (quadratic, $p=$ 0.023). C. perfringens reduced as the DFRB concentration increased from $0 \%$ to $14 \%$ and then increased. When D-lactate, total bacteria, Escherichia coli, Bifidobacterium, and C. perfringens were considered,
\end{abstract}


the optimal substitution level of DFRB were $12.00 \%, 11.84 \%, 7.50 \%, 8.92 \%$, and $15.92 \%$, respectively. In conclusion, $7 \%$ DFRB had a beneficial effect on intestinal wall thickness, Bifidobacterium and C. perfringens, and had no adverse effect on intestinal permeability and Escherichia coli.

Keywords: defatted rice bran; corns; intestinal barrier; bacteria

\section{Introduction}

In China, the largest pig-raising country in the world, feed resources are gradually scarce, and the imports of some grain crops including corns are increasing. During the last decade, the pattern of the feed industry has changed dramatically in price and accessibility of animal feed raw materials [1]. Therefore, it is an urgent problem to find alternatives to grain feed materials. The supply of milling by-products, which is a rich source of dietary fiber (DF), has increased. It is essential to understand the effects of these new and potential DF sources on gut health in pigs. A lot was already known about the impact of DF on swine nutrition [2-6]. In addition, people are increasingly interested in adding dietary fiber to pig diets because DF has been found to modulate gut microbiota and improve gut health [7].

Defatted rice bran (DFRB), an abundant and underutilized agricultural coproduct of the brown rice refining process, is rich in energy and DF [8,9]. The concentration of soluble dietary fiber and insoluble dietary fiber were $1.4 \%$ and $26.1 \%$ in DFRB, respectively (measured value of the present study). Ingredients of DFRB usually increase beneficial bacteria, reduce potentially pathogenic bacteria populations, and improve gut barrier function [10-13]. Some studies have indicated that addition of rice bran in diets may have a prebiotic effect. Addition of $10 \%$ and $20 \%$ full fatted rice bran (FFRB) in mice diets significantly reduced the enteric burden of Salmonella infection and increased Lactobacillus [13]. Adding 10\% rice bran to mice diets increased Lactobacillus [10]. Addition of 10\% rice bran improved feed utilization efficiency and tended to increase intestinal Bifidobacteria in weaning pigs [14]. Arabinoxylan (insoluble dietary fiber) reduced colonic mucosa permeability of healthy humans [11].

However, the high level of DFRB may have a negative effect on growth performance, intestinal bacteria, and gut barrier function because of the high concentration of DF. Warren et al. [15] found addition of $10 \%$ or $20 \%$ DFRB to growing pigs' diets had no effect on growth performance, but addition of 30\% reduced gain to feed ratio (G:F). Gloria et al. [16] found that average daily feed intake (ADFI) increased linearly and G:F decreased linearly as DFRB increased from $0 \%$ to $30 \%$ in the diets of finishing pigs. The high mixed-linked $\beta$-glucan (soluble dietary fiber) in diets fed to piglets significantly reduced numbers of Lactobacilli in the small intestine and decreased the microbial diversity in the colon [17]. Addition of $10 \%$ guar gum which is rich in soluble dietary fiber increased colonization of enterotoxigenic E. coli and reduced body weight gain in pigs infected with enterotoxigenic E. coli [18].

Our previous study has shown that the growth performance of Suhuai finishing pigs were not affected by $28 \%$ DFRB [19]. Intestinal barrier function and bacteria are very important to porcine health, whereas effects of increasing levels of DFRB on intestinal barrier function and bacteria was not clear. We hypothesized that moderate levels of DF may improve intestinal barrier function and beneficial bacteria, but excessive levels of DF may have a negative effect on them, and there is an optimal replacement of DFRB for porcine intestinal health.

Therefore, the aims of this study were to assess the effects of increasing levels of DFRB as a replacement for corns on intestinal physical barrier function and bacteria and determine the optimal substitution level of DFRB in finishing pigs. 


\section{Materials and Methods}

\subsection{Experimental Design and Animal Management}

A total of 35 Suhuai castrated finishing pigs (age: $158.5 \pm 2.0 \mathrm{~d}$, initial body weight: $62.9 \pm 0.8 \mathrm{~kg}$ ) were blocked by initial body weight and randomly divided into one of five experimental diets using a complete randomized block design. Suhuai pig is a new breed that is bred by Chinese Huai pig (25\%) and Western Large white pig (75\%). The five treatments included a control group and four experimental groups in which maize was separately replaced by $7 \%, 14 \%, 21 \%$, and $28 \%$ DFRB. All pigs were fed by the Osborne Testing Stations System (OTSS) and it can accurately record daily intake, daily weight gain for each pig. Therefore, each pig was identified as a replicate and there were seven replicates in each treatment. The size of each pen was $5.25 \times 2.50 \mathrm{~m}$. The pre-feeding period of the trial was 10 days and all pigs were fed with the same control diet during this period. The feeding experiment lasted $28 \mathrm{~d}$. The finishing body weight of control group, 7\%, 14\%, 21\%, and 28\% DFRB group were $82.7 \pm 2.1,82.2 \pm 2.0,84.8 \pm 2.1,83.9 \pm 3.0$, and $84.8 \pm 2.9 \mathrm{~kg}$, respectively. All the pigs were held in the same pigsty with a half seam floor, air-source heat pumps, and a fan system. The temperature inside the piggery varied from 15.5 to $19.6{ }^{\circ} \mathrm{C}$ for the whole experimental period. Pigs had ad libitum access to feed by OTSS and water by water-saving type stainless-steel drinker. Pigs were healthy and no mortality or diarrhea was observed throughout the experiment. The experimental protocol and procedures were approved by the Animal Care and Use Committee of Nanjing Agricultural University, China (with protocol SYXK (Su) 2017-0007).

\subsection{Diet Design}

The basal diet used for pigs was formulated according to the Feeding Standard of Swine 60-90 kg Standard of Meat-fat Type Growing-finishing Pig (NY/T 65-2004). It was mainly maize that was replaced by $7 \%, 14 \%, 21 \%$, and $28 \%$ DFRB in four experimental diets. In addition to maize, the other raw materials including wheat bran, soybean oil, lysine also made a small change in four experimental diets to balance metabolic energy and amino acids among five groups. The feed was produced by Huaian Zhengchang Feed Co., Ltd. (Jiangsu, China). Crude protein (CP), crude fiber (CF), ether extract (EE), acid detergent fiber (ADF), neutral detergent fiber (NDF), and hemicellulose contents of corn and DFRB are summarized in Table 1. The chemical characteristics of five diets were analyzed as previously described [20] and presented in Table 2.

Table 1. Nutrient level of corn and DFRB.

\begin{tabular}{ccc}
\hline Ingredients (\%) & Corn & DFRB \\
\hline CP & 10.62 & 18.54 \\
CF & 2.42 & 10.88 \\
EE & 5.49 & 2.90 \\
ADF & 3.24 & 11.39 \\
NDF & 11.12 & 30.09 \\
Hemicellulose $^{1}$ & 7.82 & 18.44 \\
\hline
\end{tabular}

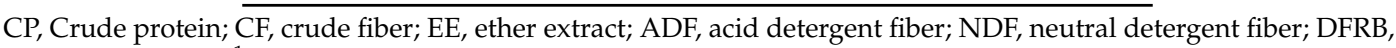
defatted rice bran; ${ }^{1}$ Hemicellulose $=$ NDF - ADF. 
Table 2. Ingredients and nutrient level of the experimental diets.

\begin{tabular}{|c|c|c|c|c|c|}
\hline \multirow{2}{*}{ Items } & \multicolumn{5}{|c|}{ Diet } \\
\hline & Control & $7 \%$ & $14 \%$ & $21 \%$ & $28 \%$ \\
\hline \multicolumn{6}{|l|}{ Ingredients (\%) } \\
\hline Corns & 68.61 & 62.00 & 55.00 & 48.00 & 41.00 \\
\hline Wheat bran & 15.40 & 15.80 & 16.15 & 16.67 & 17.21 \\
\hline DFRB & 0.00 & 7.00 & 14.00 & 21.00 & 28.00 \\
\hline Soybean meal & 13.30 & 11.70 & 10.40 & 8.95 & 7.50 \\
\hline Soybean oil & 0.00 & 0.84 & 1.83 & 2.78 & 3.74 \\
\hline 98.5\% Lysine & 0.03 & 0.04 & 0.03 & 0.03 & 0.03 \\
\hline Salt & 0.30 & 0.30 & 0.30 & 0.30 & 0.30 \\
\hline Limestone & 0.82 & 0.85 & 0.85 & 0.85 & 0.85 \\
\hline $\mathrm{CaHPO}_{4}$ & 0.75 & 0.68 & 0.65 & 0.63 & 0.58 \\
\hline $60 \%$ Choline & 0.04 & 0.04 & 0.04 & 0.04 & 0.04 \\
\hline Premix ${ }^{1}$ & 0.40 & 0.40 & 0.40 & 0.40 & 0.40 \\
\hline \multicolumn{6}{|l|}{ Nutrient level $^{2}$} \\
\hline DM (\%) & 88.56 & 88.68 & 88.93 & 89.16 & 88.46 \\
\hline Digestible energy/(MJ.kg-1) & 13.13 & 13.13 & 13.13 & 13.13 & 13.13 \\
\hline $\mathrm{CP}(\%)$ & 15.60 & 16.67 & 16.13 & 15.73 & 16.40 \\
\hline CF $(\%)$ & 8.89 & 11.80 & 12.93 & 14.35 & 17.94 \\
\hline Calcium (\%) & 0.55 & 0.55 & 0.55 & 0.55 & 0.55 \\
\hline Available phosphorus (\%) & 0.27 & 0.27 & 0.27 & 0.27 & 0.27 \\
\hline L-lysine $(\%)$ & 0.65 & 0.65 & 0.65 & 0.66 & 0.65 \\
\hline Methionine + cystine $(\%)$ & 0.45 & 0.45 & 0.46 & 0.47 & 0.47 \\
\hline $\operatorname{IDF}(\%)$ & 16.14 & 17.19 & 18.42 & 19.32 & 23.37 \\
\hline SDF (\%) & 0.52 & 0.56 & 0.68 & 0.73 & 0.82 \\
\hline TDF $(\%)$ & 16.70 & 17.75 & 19.10 & 20.05 & 24.11 \\
\hline $\operatorname{ADF}(\%)$ & 5.53 & 6.25 & 6.53 & 7.08 & 8.13 \\
\hline NDF $(\%)$ & 8.89 & 11.80 & 12.93 & 14.35 & 17.94 \\
\hline $\mathrm{EE}(\%)$ & 5.19 & 5.08 & 5.32 & 5.27 & 5.38 \\
\hline Hemicellulose (\%) & 3.80 & 5.69 & 7.09 & 8.00 & 10.34 \\
\hline Cellulose $(\%)$ & 4.06 & 4.43 & 4.71 & 5.09 & 5.79 \\
\hline Lignin (\%) & 0.46 & 0.54 & 0.72 & 0.96 & 1.13 \\
\hline
\end{tabular}

${ }_{1}$ The premix provided the following per kg of diets: vitamin A $8000 \mathrm{IU}$, vitamin $\mathrm{E} 100 \mathrm{mg}$, vitamin $\mathrm{K}_{3} 4 \mathrm{mg}$, vitamin $\mathrm{D}_{3} 1500 \mathrm{IU}$, vitamin $B_{1} 2 \mathrm{mg}$, vitamin $B_{2} 8 \mathrm{mg}$, vitamin $B_{6} 3 \mathrm{mg}$, vitamin $B_{12} 0.04 \mathrm{mg}$, niacin $30 \mathrm{mg}$, Choline $150 \mathrm{mg}$, biotin $0.13 \mathrm{mg}$, folic acid $0.6 \mathrm{mg}$, pantothenic acid $35 \mathrm{mg}$, Fe $60 \mathrm{mg}$, Cu $5 \mathrm{mg}$, Zn $60 \mathrm{mg}$, Mn $10 \mathrm{mg}$, Se $0.15 \mathrm{mg}$, I $0.1 \mathrm{mg} .{ }^{2} \mathrm{DM}$, dry matter, $\mathrm{CP}$, crude protein, $\mathrm{CF}$, crude fiber, IDF, insoluble dietary fiber, SDF, soluble dietary fiber, $\mathrm{TDF}$, total dietary fiber, $\mathrm{EE}$, ether extract, $\mathrm{ADF}$, acid detergent fiber, NDF, neutral detergent fiber, DFRB, defatted rice bran. DM, CP, CF, IDF, SDF, ADF, NDF, EE, hemicellulose, cellulose and lignin were measured values, while the other nutrient levels were calculated values.

\subsection{Sample Collection}

After the 28-d trial, blood samples were collected from jugular vein and centrifuged at $3000 \times g$ at $4{ }^{\circ} \mathrm{C}$ for $10 \mathrm{~min}$ to collect serum [21]. The serum was stored at $-80{ }^{\circ} \mathrm{C}$ until further analyses of endotoxin, diamine oxidase (DAO), and D-lactate. All pigs were stunned by electric shock and slaughtered. The abdomen of each pig was immediately opened, and the jejunum, cecum, and colon were removed. The middle sections $(1 \mathrm{~cm})$ of the colon and cecum were collected and then fixed in $4 \%$ paraformaldehyde for histological analysis. Mucosal scrapings from the jejunum, ileum, and colon were prepared and stored at $-80^{\circ} \mathrm{C}$ for measuring $16 \mathrm{~S}$ rRNA gene copy numbers in bacteria and the mRNA levels of Caspase 3, Bax, and Bcl-2L1. 


\subsection{Histological Measurements}

Since fibers are mainly fermented in the large intestine and may have an impact on morphology of the large intestine, we only measured caecal and colonic mucosal morphology. Crypt depth and thickness of the intestinal wall were determined as described by Shen et al. [22]. Fixed intestinal segments were dehydrated with alcohol and encapsulated with paraffin. Consecutive sections at $5 \mu \mathrm{m}$ thickness were stained with hematoxylin-eosin for histology morphological measurements. The crypt depth was determined on well oriented crypts as distance from the crypt mouth to the crypt base at the basement membrane. Thickness of the intestinal wall was determined as vertical distance from the lateral side of the intestinal wall to the crypt mouth. Crypt depth and thickness of the intestinal wall was measured with a Nikon Eclipse 80i microscope (Nikon Company, Tokyo, Japan).

\subsection{Blood Sample Analysis}

According to the manufacturer's instructions, the levels of endotoxin, D-lactate, and DAO in the serum were measured by a reagent kit (Jiancheng Bioengineering Institute of Nanjing, Nanjing, Jiangsu, China). The range of the detection of endotoxin, D-lactate, and DAO was $0-1600 \mathrm{EU} / \mathrm{L}, 0-4.8 \mu \mathrm{g} / \mathrm{L}$, and 0-80 ng/mL, respectively. Serum was diluted 10 times when D-lactate was measured.

\subsection{DNA Isolation, Design, and Validation of Primers for Total Bacteria Escherichia coli, Clostridium} perfringens, Bifidobacterium and Lactobacillus

Bacterial DNA of the intestinal mucosal scrapings was extracted by FastDNA ${ }^{\circledR}$ Spin Kit for Soil (MP Biomedicals, Irvine, CA, USA). All the primers (Table 3) were commercially synthesized by Beijing Tsingke Biotech Co., Ltd. DNA quality and concentration of were measured using UL-1000 (Shanghai Meixi Instrument Co., Ltd., Shanghai, China). For the quantification of bacteria in samples, standard curves were made by constructing standard plasmids, as described by Han et al. [23]. The specific PCR product of target bacteria was purified by the Cycle Pure Kit PCR (OMEGA Bio-tek, Norcross, GA, USA), and inserted into a Versatile Simple Vector (TsingKe, Nanjing, China). The plasmid DNA was extracted using the AxyPrep ${ }^{\mathrm{TM}}$ Plasmid Miniprep Kit (AXYGEN, Fremont, CA, USA) and standard plasmids were constructed successfully. The copies were calculated by the following formula: $\left(6.0233 \times 10^{23}\right.$ copies $/ \mathrm{mol} \times$ DNA concentration $\left.(\mu \mathrm{g} / \mathrm{mL})\right) /\left(660 \times 10^{9} \times\right.$ DNA size $\left.(\mathrm{bp})\right)$. A 10 -fold serial dilution series of plasmid DNA was used to construct the standard curves for total bacteria, E. coli, C. perfringens, Lactobacillus, and Bifidobacterium. Each standard curve was constructed by linear regression of the plotted points, and cycle threshold (CT) values were plotted against the logarithm of template copy numbers. Quantitative analysis of PCR was performed with TB Green ${ }^{\circledR}$ Premix Ex Taq ${ }^{\text {TM }}$ II (TaRaKa Biotechnology, Shiga, Japan) by an ABI QuantStudio 3 Real-Time PCR System (Applied Biosystems, Foster City, CA, USA). 
Table 3. Primers used for real-time PCR.

\begin{tabular}{|c|c|c|}
\hline Target & Primer Sequence $\left(5^{\prime}-3^{\prime}\right)$ & Reference \\
\hline \multicolumn{3}{|c|}{ Total bacteria } \\
\hline Forward & ACTCCTACGGGAGGCAGCAG & {$[24]$} \\
\hline Reverse & ATTACCGCGGCTGCTGG & \\
\hline \multicolumn{3}{|c|}{ Escherichia coli } \\
\hline Forward & CATGCCGCGTGTATGAAGAA & [25] \\
\hline Reverse & CGGGTAACGTCAATGAGCAAA & \\
\hline \multicolumn{3}{|c|}{ C. perfringens } \\
\hline Forward & CGCATAACGTTGAAAGATGG & [26] \\
\hline Reverse & CCTTGGTAGGCCGTTACCC & \\
\hline \multicolumn{3}{|l|}{ Lactobacillus } \\
\hline Forward & GCAGCAGTAGGGAATCTTCCA & [27] \\
\hline Reverse & GCATTYCACCGCTACACATG & \\
\hline \multicolumn{3}{|c|}{ Bifidobacterium } \\
\hline Forward & CGGGTGAGTAATGCGTGACC & [28] \\
\hline Reverse & TGATAGGACGCGACCCCA & \\
\hline \multicolumn{3}{|l|}{ GAPDH } \\
\hline Forward & GTCGGAGTGAACGGATTTGG & [29] \\
\hline Reverse & CAATGTCCACTTTGCCAGAGTTAA & \\
\hline \multicolumn{3}{|l|}{$B c l-2 L 1$} \\
\hline Forward & TGAATCAGAAGCGGAAACCC & [30] \\
\hline \multicolumn{2}{|r|}{ 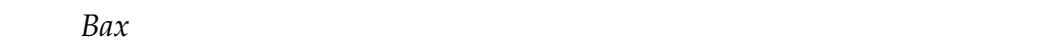 } & \\
\hline Forward & AAGCGCATTGGAGATGAACT & [30] \\
\hline Reverse & CGATCTCGAAGGAAGTCCAG & \\
\hline \multicolumn{3}{|l|}{ Caspase 3} \\
\hline Forward & ACACGCCATGTCATCTTCAGTCC & [30] \\
\hline Reverse & TTCATAATTCAGGCCTGCCGAG & \\
\hline
\end{tabular}

\subsection{Real-Time Quantitative PCR}

Caspase-3 is considered to be the most important apoptotic executor, and its activation is a marker of irreversible apoptosis. Bcl-2L1 protein family plays an important role in regulating apoptosis, in which $B c l 2$ is an anti-apoptotic gene and Bax is a pro-apoptotic gene. All of them play an important role in the process of apoptosis. To evaluate the effects of increasing levels of DFRB as a replacement for corns on intestinal cell proliferation and apoptosis of finishing pigs, the mRNA levels of Caspase 3, $B a x$, and $B c l-2 L 1$ were detected by real-time quantitative PCR.

According to the manufacturer's guidelines, total RNA of intestinal mucosa was extracted using TRIZOL (Shanghai Yuanye Biotechnology Co., Ltd., Shanghai, China). The RNA concentration and quality were measured using UL-1000 (Shanghai Meixi Instrument Co., Ltd., Shanghai, China). The RNA samples were reverse transcribed into complementary DNA using 5X All-In-One RT MasterMix (Applied Biological Materials, Richmond, B.C., Canada). Quantitative analysis of PCR was performed with TB Green ${ }^{\circledR}$ Premix Ex Taq ${ }^{\text {TM }}$ II (TaRaKa, Shiga, Japan) by an ABI QuantStudio 3 Real-Time PCR System (Applied Biosystems, Foster City, CA, USA).

The reaction was performed using the following cycle program: a hold stage at $95^{\circ} \mathrm{C}$ for $10 \mathrm{~min}$; 35 cycles for PCR stage at $95^{\circ} \mathrm{C}$ for $15 \mathrm{~s}$ and at $60^{\circ} \mathrm{C}$ for $60 \mathrm{~s}$; a melt curve stage at $95^{\circ} \mathrm{C}$ for $15 \mathrm{~s}$, at $60^{\circ} \mathrm{C}$ for $60 \mathrm{~s}$, and at $95{ }^{\circ} \mathrm{C}$ for $1 \mathrm{~s}$. All samples were analyzed for three repetitions. The relative expression of the Caspase 3, Bax, and Bcl-2L1 mRNA was calculated using the $2^{-\Delta \Delta C t}$ method [31]. 


\subsection{Statistical Analysis}

Bacterial 16S rRNA gene copy numbers were transformed (log 10) before statistical analysis. Linear and quadratic effects of dietary treatments on all indices were determined by curve estimation and some indices including serum endotoxins, DAO and Escherichia coli in the jejunum in Appendix A Table A1 were also analyzed by one-way ANOVA (SPSS 25.0) (SPSS Inc., Chicago, IL, USA). DFRB was the main effect. Each pig was considered as the experimental unit for all analyses. The $\alpha$-level was set as 0.05 for significance determination. Data are presented as means with their pooled standard errors. The linear effects was determined by equation:

$$
\mathrm{y}=\mathrm{a}+\mathrm{bx}
$$

where $\mathrm{y}$ is dependent variable, and $\mathrm{x}$ is the content of DFRB.

The optimal substitution level of corn by DFRB was predicted by quadratic regression equation as described by Souza et al. [32]. Quadratic regression equation:

$$
y=a+b x+c x^{\wedge} 2
$$

$$
\text { the optimal substitution level }(\%)=-b / 2 \times c
$$

where $\mathrm{y}$ is dependent variable, and $\mathrm{x}$ is the content of DFRB.

\section{Results}

\subsection{Effects of Varying DFRB Levels on Intestinal Permeability}

Serum endotoxins, D-lactate concentration, and DAO activity are shown in Table 4. Serum endotoxins concentration and DAO activity were both increased (linear, $p=0.0004,0.001$, respectively) as the DFRB content of the diets increased. However, compared with control group, serum endotoxins concentration and DAO activity were not different in pigs fed with 7\% DFRB in the diet (Appendix A Table A1). There was a quadratic response in serum D-lactate concentration to the increased DFRB

\begin{tabular}{|c|c|c|c|c|c|c|c|c|}
\hline \multirow{2}{*}{ Item } & \multicolumn{5}{|c|}{ Diet } & \multirow{2}{*}{ SEM } & \multicolumn{2}{|c|}{$p$ Value } \\
\hline & Basal & $7 \%$ & $14 \%$ & $21 \%$ & $28 \%$ & & Linear & Quadratic \\
\hline Endotoxins, EU/L & 219.58 & 240.42 & 335.60 & 421.78 & 352.86 & 18.01 & $<0.001$ & $<0.001$ \\
\hline D-lactate, $\mu \mathrm{g} / \mathrm{L}$ & 4.86 & 4.00 & 4.42 & 4.89 & 5.15 & 0.36 & 0.102 & 0.021 \\
\hline $\mathrm{DAO}, \mathrm{ng} / \mathrm{mL}^{2}$ & 23.38 & 27.39 & 23.71 & 35.16 & 32.23 & 1.16 & 0.001 & 0.005 \\
\hline
\end{tabular}
(quadratic, $p=0.021$ ).

Table 4. Effects of varying defatted rice bran levels on intestinal permeability ${ }^{1}$.

${ }^{1}$ Values are means and pooled SEMs, $\mathrm{n}=7 .{ }^{2} \mathrm{DAO}$, diamine oxidase; SEM, standard error of mean.

\subsection{Effect of Varying DFRB Levels on Intestinal Morphology}

We observed the effects of varying DFRB levels on intestinal morphology (Table 5). The thickness of the intestinal wall significantly increased with the increasing level of DFRB in the diets (linear, $p=0.033$ ), while crypt depth/thickness of the intestinal wall ratio significantly decreased with the increasing level of DFRB in the diets (linear, $p=0.043$ ) in the cecum. Crypt depth was not influenced by the level of DFRB in the diet in the cecum. Moreover, the crypt depth, thickness of the intestinal wall, and crypt depth/thickness of the intestinal wall ratio in the colon were not influenced by the level of DFRB in the diet. 
Table 5. Effect of varying defatted rice bran levels on intestinal morphology.

\begin{tabular}{|c|c|c|c|c|c|c|c|c|}
\hline \multirow{2}{*}{ Item } & \multicolumn{5}{|c|}{ Diet } & \multirow{2}{*}{ SEM } & \multicolumn{2}{|c|}{$p$ Value } \\
\hline & Basal & $7 \%$ & $14 \%$ & $21 \%$ & $28 \%$ & & Linear & Quadratic \\
\hline Cecum & & & & & & & & \\
\hline Crypt depth, $\mu \mathrm{m}$ & 452.03 & 450.95 & 462.07 & 434.32 & 448.66 & 22.13 & 0.631 & 0.884 \\
\hline $\begin{array}{l}\text { Thickness of the } \\
\text { intestinal wall, } \mu \mathrm{m}\end{array}$ & 1253.06 & 1319.43 & 1348.21 & 1409.07 & 1336.48 & 30.12 & 0.033 & 0.021 \\
\hline $\mathrm{CD} / \mathrm{IWT}^{1}$ & 0.36 & 0.34 & 0.34 & 0.31 & 0.34 & 0.01 & 0.043 & 0.063 \\
\hline Colon & & & & & & & & \\
\hline Crypt depth, $\mu \mathrm{m}$ & 420.31 & 431.61 & 355.04 & 418.50 & 405.18 & 29.73 & 0.546 & 0.470 \\
\hline $\begin{array}{l}\text { Thickness of the } \\
\text { intestinal wall, } \mu \mathrm{m}\end{array}$ & 1115.69 & 1187.08 & 1425.81 & 1130.41 & 1262.36 & 28.79 & 0.251 & 0.116 \\
\hline $\mathrm{CD} / \mathrm{IWT}$ & 0.38 & 0.37 & 0.25 & 0.37 & 0.32 & 0.12 & 0.210 & 0.127 \\
\hline
\end{tabular}

${ }^{1} \mathrm{CD} / \mathrm{IWT}$, Crypt depth/thickness of the intestinal wall ratio. Values are means and pooled SEMs, $\mathrm{n}=7$. SEM, standard error of mean.

\subsection{Effect of Varying DFRB Levels on $16 S$ rRNA Gene Copy numbers in Bacteria}

The effects of varying DFRB levels on 16S rRNA gene copy numbers in bacteria are reported in Table 6. In the jejunum, total bacteria, Escherichia coli, and Bifidobacterium all responded quadratically to increasing levels of DFRB in the diets (quadratic, $p=0.003,0.001,0.006$, respectively) while $C$. perfringens and Lactobacillus were not influenced by the level of DFRB in the diets. There was no difference in Escherichia coli in pigs fed 0\%,7\%, and 14\% DFRB diets (Appendix A Table A1). In the ileum, total bacteria, Escherichia coli, C. perfringens, Lactobacillus, and Bifidobacterium were not influenced by the level of DFRB in the diets. In the colon, there were quadratic responses in C. perfringens to the increased DFRB (quadratic, $p=0.023$ ). $C$. perfringens reduced as the DFRB concentration increased from $0 \%$ to $14 \%$ and then increased as the DFRB concentration increased from $14 \%$ to $28 \%$.

Table 6. Effect of varying defatted rice bran levels on $16 \mathrm{~S}$ rRNA gene copy numbers in bacteria, $\mathrm{lg}$ (copies/g) ${ }^{1}$.

\begin{tabular}{|c|c|c|c|c|c|c|c|c|}
\hline \multirow{2}{*}{ Item } & \multicolumn{5}{|c|}{ Diet } & \multirow{2}{*}{ SEM } & \multicolumn{2}{|c|}{$p$ Value } \\
\hline & Basal & $7 \%$ & $14 \%$ & $21 \%$ & $28 \%$ & & Linear & Quadratic \\
\hline \multicolumn{9}{|l|}{ Jejunum } \\
\hline Total bacteria & 6.84 & 6.51 & 6.49 & 6.59 & 7.27 & 0.17 & 0.140 & 0.003 \\
\hline Escherichia coli & 5.17 & 4.00 & 5.08 & 6.20 & 6.58 & 0.54 & 0.002 & 0.001 \\
\hline C. perfringens & 2.10 & 1.78 & 1.52 & 2.03 & 1.95 & 0.16 & 0.810 & 0.156 \\
\hline Lactobacillus & 5.53 & 6.39 & 4.35 & 4.96 & 5.39 & 0.49 & 0.379 & 0.402 \\
\hline Bifidobacterium & 4.88 & 5.02 & 4.82 & 4.91 & 4.44 & 0.10 & 0.014 & 0.006 \\
\hline \multicolumn{9}{|l|}{ Ileum } \\
\hline Total bacteria & 8.53 & 7.29 & 8.43 & 8.15 & 8.37 & 0.13 & 0.987 & 0.647 \\
\hline Escherichia coli & 6.29 & 5.40 & 6.02 & 4.86 & 6.29 & 0.14 & 0.559 & 0.079 \\
\hline C. perfringens & 3.15 & 2.70 & 3.01 & 2.43 & 3.14 & 0.12 & 0.509 & 0.086 \\
\hline Lactobacillus & 7.19 & 5.37 & 7.30 & 5.76 & 6.75 & 0.18 & 0.394 & 0.509 \\
\hline Bifidobacterium & 6.39 & 5.29 & 6.35 & 5.24 & 6.34 & 0.11 & 0.619 & 0.163 \\
\hline \multicolumn{9}{|l|}{ Colon } \\
\hline Total bacteria & 8.33 & 7.60 & 8.08 & 8.01 & 7.76 & 0.13 & 0.160 & 0.303 \\
\hline Escherichia coli & 5.75 & 5.39 & 5.60 & 4.92 & 5.13 & 0.33 & 0.123 & 0.305 \\
\hline C. perfringens & 4.05 & 3.41 & 2.98 & 3.36 & 3.63 & 0.24 & 0.277 & 0.023 \\
\hline Lactobacillus & 6.97 & 5.39 & 6.51 & 6.77 & 6.31 & 0.48 & 0.956 & 0.482 \\
\hline Bifidobacterium & 5.01 & 5.27 & 5.00 & 4.83 & 5.08 & 0.12 & 0.437 & 0.741 \\
\hline
\end{tabular}

\footnotetext{
${ }^{1}$ Values are means and pooled SEMs, $\mathrm{n}=7$. SEM, standard error of mean.
} 


\subsection{Effect of Varying DFRB Levels on Intestinal Gene Expression}

The mRNA levels of Caspase 3, Bax, and Bcl-2L1 were not influenced by the level of DFRB in the diets in jejunum, ileum, and colon.

\subsection{Calculation of the Optimal Substitution Level of DFRB}

The result of the calculation of the optimal substitution level of DFRB for corns is shown in Table 7. In this experiment, five indicators including D-lactate, total bacteria, Escherichia coli, Bifidobacterium, and C. perfringens were quadratically correlated with the level of DFRB. They were used to calculate the optimal substitution level of DFRB for maize. When D-lactate, total bacteria, Escherichia coli, Bifidobacterium, and C. perfringens were considered, the optimal substitution level of DFRB was $12.00 \%$, $11.84 \%, 7.50 \%, 8.92 \%$, and $15.92 \%$, respectively.

Table 7. The optimal substitution level of corns by defatted rice bran in Suhuai finishing pigs.

\begin{tabular}{ccccc}
\hline Item & $\mathbf{a}^{\mathbf{1}}$ & $\mathbf{b}$ & $\mathbf{c}$ & Inflexion Point (\%) \\
\hline D-lactate & 4.697 & -0.072 & 0.003 & 12.00 \\
Total bacteria & 6.854 & -0.073 & 0.003 & 11.84 \\
Escherichia coli & 4.931 & -0.105 & 0.007 & 7.50 \\
Bifidobacterium & 4.878 & 0.023 & -0.001 & 8.92 \\
C. perfringens & 4.045 & -0.121 & 0.004 & 15.92 \\
\hline \multicolumn{7}{r}{ a-c are coefficients of constant term, primary term and quadratic term, respectively. }
\end{tabular}

\section{Discussion}

Integrated intestinal mucosal barrier is important for the defense of pathogenic bacteria $[33,34]$. The intestinal permeability can be increased by the injured intestinal mucosal barrier. The intestinal barrier function has to do with many factors, including endotoxins, D-lactate concentration, and DAO activity in serum [35-38]. They have been considered as markers for evaluating the extent of intestinal mucosal damage and repair [39]. As one of the secretions of Escherichia coli, serum endotoxins activity increased with increased intestinal permeability or injury to intestinal barrier integrity [40]. D-Lactate is the end product of intestinal bacteria. Mammals produced neither D-lactate nor D-lactate dehydrogenase. Hence, they maintain a lower level of D-Lactate in healthy conditions [41]. When intestinal mucosal integrity is impaired, almost all D-lactate will release into the blood. Thus, this indicates that serum D-Lactate reflects the integrity and maturity of intestinal mucosa [42]. DAO is one of the DAO catalyzed by deaminases, only exists in the villi of the upper small intestine, and its increasing concentrations indicate increased intestinal epithelial permeability or damage to intestinal barrier function $[43,44]$. Serum endotoxins concentration and DAO activity were both increased with the DFRB level. There was a quadratic response in serum D-lactate concentration to the increased DFRB. However, compared with control group, serum endotoxins concentration and DAO activity were not different in pigs fed with 7\% DFRB in the diet. Therefore, $7 \%$ DFRB had had no adverse effect on intestinal permeability.

On the other hand, integral morphological structure is important for the intestinal tract to maintain the ability to secret, digest, and absorb nutrients. As fibers are mainly fermented in the large intestine and may have an impact on morphology of the large intestine, we only measured cecal and colonic mucosal morphology. The present study showed that colonic morphology was not influenced by the increased DFRB. However, in the cecum, thickness of the intestinal wall significantly increased with increasing level of DFRB in the diets while crypt depth/thickness of the intestinal wall ratio decreased with the increasing level of DFRB in the diets. One possible explanation for this result is that muscle thickness increased but crypt depth remained unchanged with the increasing level of DFRB in the diets. Additionally, increased muscle thickness may increase the mixing of intestinal contents to increase digestibility of the DF. 
The intestinal microflora is very important to intestinal health, not only because the imbalance of the microflora may lead to an inflammation response, but also may compete with the host for nutrients [45]. The microflora enhances the intestinal mucosa barrier function and reduces the adhesion of pathogenic microorganisms to the mucosa, thus reducing the chance of pathogenic microorganisms entering enterocytes. Lactobacillus and Bifidobacteria are the main beneficial bacteria in the intestinal tract of mammals. They play a resistant role against intestinal pathogens through a variety of mechanisms. Lactobacillus is considered to be a reflection of changes in the population structure of beneficial bacteria because a large number of intestinal bacteria cannot be cultured [46]. It is controversial to consider $E$. coli as a marker of pathogenic bacteria; however, the number of $E$. coli increased in the intestinal tract of diarrhea pigs [47]. Therefore, the reduction of E. coli caused by dietary intervention is considered to be beneficial by many people to a certain extent [48-50]. Many studies have shown that DF is beneficial to the proliferation of beneficial bacteria and inhibits harmful bacteria. Drew et al. [51] found that wheat-based diets increased Bifidobacterium and reduced total aerobes and Clostridium. Similarly, Nielsen et al. [52] reported that addition of arabinoxylan (AX) in pig diets increased Bifidobacterium and Lactobacillus in the feces. In line with the previous findings, this study shows that there were declined Escherichia coli and increased Bifidobacterium as DFRB increased from 0\% to 7\%. Escherichia coli increased and Bifidobacterium declined when 14\% DFRB was fed. One possible explanation might be that high-fiber diets have a negative effect on intestinal barrier function and is not conducive to the growth of beneficial bacteria. The high level of DFRB have a negative effect on the intestinal barrier function, which may be mediated by the changes of microbial composition and the accompanying changes of intestinal permeability.

This study shows the mRNA levels of Caspase 3, Bax, and Bcl-2L1 were not influenced by the level of DFRB in the diets in jejunum, ileum, and colon. The results showed that the addition of defatted rice bran in the diet did not affect the apoptotic process of intestinal cells. This is consistent with the previous study made by Gregoire et al. [53]. They reported that a short-term increase in dietary fiber does not result in a significant difference in cell proliferation [53]. However, Jin et al. [54] found that the number of epithelial cells exhibiting DNA fragmentation (indicating programmed cell death) was greater in growing pigs consuming the high-fiber diet than in the low-fiber diet group for jejunum and ileum. The difference in the results may be due to the different types of fibers and the different stages of animal growth.

\section{Conclusions}

In conclusion, 7\% DFRB had a beneficial effect on intestinal wall thickness, Bifidobacterium, and C. perfringens, and had no adverse effect on intestinal permeability and Escherichia coli.

Author Contributions: Conceptualization, R.H. and P.L.; methodology, H.W., T.D. and P.L.; investigation, H.W., L.F. and C.G.; resources, H.W., C.W. and P.N.; data curation, H.W., G.P. and W.Z.; writing-original draft preparation, H.W.; writing-review and editing, H.W., P.L. and R.H.; supervision, P.L.; project administration, W.Z. and P.L.; funding acquisition, R.H. and P.L.

Funding: This research was funded by the National Natural Science Foundation (31872318, 31601923), the Key Project for Jiangsu Agricultural New Variety Innovation (PZCZ201732), the Construction of Huaian Academy of Nanjing Agricultural University (BM2017020) and the Jiangsu Modern Agriculture (Pig) Industry Technology Construction Project (SXGC(2018)275).

Acknowledgments: The authors would like to thank to the Nanjing Agricultural University's New Rural Research and Development Corporation for their collaboration during the pig experiments.

Conflicts of Interest: The authors declare no conflict of interest. 


\section{Appendix A}

Table A1. The results of one-way ANOVA of serum endotoxins, diamine oxidase (DAO), and Escherichia coli in the jejunum ${ }^{1}$.

\begin{tabular}{lccccccc}
\hline \multirow{2}{*}{ Item } & \multicolumn{5}{c}{ Diet } & \multirow{2}{*}{ SEM } & \multicolumn{1}{c}{$\boldsymbol{p \text { Value }}$} \\
\cline { 2 - 5 } & Basal & $\mathbf{7 \%}$ & $\mathbf{1 4 \%}$ & $\mathbf{2 1 \%}$ & $\mathbf{2 8 \%}$ & & ANOVA \\
\hline Endotoxins, EU/L & $219.58^{\mathrm{c}}$ & $240.42^{\mathrm{c}}$ & $335.60^{\mathrm{b}}$ & $421.78^{\mathrm{a}}$ & $352.86^{\mathrm{b}}$ & 18.01 & $<0.001$ \\
$\mathrm{DAO}^{2}, \mathrm{ng} / \mathrm{mL}$ & $23.38^{\mathrm{b}}$ & $27.39^{\mathrm{ab}}$ & $23.71^{\mathrm{b}}$ & $35.16^{\mathrm{a}}$ & $32.23^{\mathrm{a}}$ & 1.16 & 0.001 \\
Escherichia coli (Jejunum) $^{\mathrm{b}}$ & $5.17^{\mathrm{ab}}$ & $4.00^{\mathrm{b}}$ & $5.08^{\mathrm{b}}$ & $6.20^{\mathrm{ab}}$ & $7.58^{\mathrm{a}}$ & 0.54 & 0.006 \\
\hline
\end{tabular}

${ }^{1}$ Means with similar lowercase letters $(a-c)$ within a row are the same $(p<0.05)$. Values are means and pooled SEMs, $\mathrm{n}=7$. SEM, standard error of mean. ${ }^{2} \mathrm{DAO}$, diamine oxidase.

\section{References}

1. Jha, R.; Berrocoso, J.D. Review: Dietary fiber utilization and its effects on physiological functions and gut health of swine. Animal 2015, 9, 1441-1452. [CrossRef]

2. Gutierrez, N.A.; Serao, N.V.; Kerr, B.J.; Zijlstra, R.T.; Patience, J.F. Relationships among dietary fiber components and the digestibility of energy, dietary fiber, and amino acids and energy content of nine corn coproducts fed to growing pigs. J. Anim. Sci. 2014, 92, 4505-4517. [CrossRef]

3. Shurson, G.C.; Zijlstra, R.T.; Kerr, B.J.; Stein, H.H. Feeding biofuels co-products to pigs. In Biofuel Co-Products as Livestock Feed-Opportunities and Challenges; Makkar, H.P., Ed.; FAO: Rome, Italy, 2012; pp. 175-207.

4. Schneeman, B.O. Dietary fiber and gastrointestinal function. Nutr. Res. 2010, 45, 129-132.

5. Urriola, P.E.; Shurson, G.C.; Stein, H.H. Digestibility of dietary fiber in distillers coproducts fed to growing pigs. J. Anim. Sci. 2010, 88, 2373-2381. [CrossRef] [PubMed]

6. Zijlstra, R.T. Swine convert co-products from food and biofuel industries into animal protein for food. Anim. Front. 2013, 3, 48-53. [CrossRef]

7. Williams, B.A.; Verstegen, M.W.; Tamminga, S. Fermentation in the large intestine of single-stomached animals and its relationship to animal health. Nutr Res. Rev. 2001, 14, 207-228. [CrossRef]

8. Ryan, E.P. Bioactive food components and health properties of rice bran. J. Am. Vet. Med. Assoc. 2011, 238, 593-600. [CrossRef]

9. García-Lara, S. Cereal Grains: Properties, Processing and Nutritional Attributes. Crop. Sci. 2010, 50, 2649. [CrossRef]

10. Henderson, A.J.; Kumar, A.; Barnett, B.; Dow, S.W.; Ryan, E.P. Consumption of rice bran increases mucosal immunoglobulin A concentrations and numbers of intestinal Lactobacillus spp. J. Med. Food 2012, 15, 469-475. [CrossRef]

11. Ganda, J.P.; Lofvendahl, L.; Lindqvist, C.M.; Brummer, R.J.; Keita, A.V.; Schoultz, I. Differential effects of dietary fibres on colonic barrier function in elderly individuals with gastrointestinal symptoms. Sci. Rep. 2018, 8, 13404. [CrossRef]

12. Ghatak, S.B.; Panchal, S.J. Investigation of the immunomodulatory potential of oryzanol isolated from crude rice bran oil in experimental animal models. Phytother. Res. 2012, 26, 1701-1708. [CrossRef] [PubMed]

13. Kumar, A.; Henderson, A.; Forster, G.M.; Goodyear, A.W.; Weir, T.L.; Leach, J.E.; Dow, S.W.; Ryan, E.P. Dietary rice bran promotes resistance to Salmonella enterica serovar Typhimurium colonization in mice. BMC Microb. 2012, 12, 71. [CrossRef] [PubMed]

14. Herfel, T.; Jacobi, S.; Lin, X.; van Heugten, E.; Fellner, V.; Odle, J. Stabilized rice bran improves weaning pig performance via a prebiotic mechanism. J. Anim. Sci. 2013, 91, 907-913. [CrossRef] [PubMed]

15. Warren, B.E.; Farrell, D.J. The nutritive value of full-fat and defatted Australian rice bran. II. Growth studies with chickens, rats and pigs. Anim. Feed Sci. Technol. 1990, 27, 229-246. [CrossRef]

16. Casas, G.A.; Overholt, M.F.; Dilger, A.C.; Boler, D.D.; Stein, H.H. Effects of full fat rice bran and defatted rice bran on growth performance and carcass characteristics of growing-finishing pigs. J. Anim. Sci. 2018, 96, 2293-2309. [CrossRef]

17. Pieper, R.; Jha, R.; Rossnagel, B.; Van Kessel, A.G.; Souffrant, W.B.; Leterme, P. Effect of barley and oat cultivars with different carbohydrate compositions on the intestinal bacterial communities in weaned piglets. FEMS Microb. Ecol. 2008, 66, 556-566. [CrossRef] 
18. McDonald, D.E.; Pethick, D.; Pluske, J.; Hampson, D. Adverse effects of soluble non-starch polysaccharide (guar gum) on piglet growth and experimental colibacillosis immediately after weaning. Res. Vet. Sci. 1999, 67, 245-250. [CrossRef]

19. Pu, G.; Huang, R.; Niu, Q.; Wang, H.; Fan, L.; Gao, C.; Niu, P.; Zang, Z.; Wu, C.; Zhou, J.; et al. Effects of Dietary Defatted Rice Bran Substitute Corn Levels on Growth Performance, Intestinal Development and Apparent Digestibility of Nutrients of Suhuai Pigs. Acta Vet. Zootech. Sin. 2019, 50, 758-770.

20. Niu, Q.; Li, P.; Hao, S.; Zhang, Y.; Kim, S.W.; Li, H.; Ma, X.; Gao, S.; He, L.; Wu, W.; et al. Dynamic distribution of the gut microbiota and the relationship with apparent crude fiber digestibility and growth stages in pigs. Sci. Rep. 2015, 5, 9938. [CrossRef]

21. Yin, F.; Zhang, Z.; Huang, J.; Yin, Y. Digestion rate of dietary starch affects systemic circulation of amino acids in weaned pigs. Br. J. Nutr. 2010, 103, 1404-1412. [CrossRef]

22. Shen, Y.B.; Piao, X.S.; Kim, S.W.; Wang, L.; Liu, P.; Yoon, I.; Zhen, Y.G. Effects of yeast culture supplementation on growth performance, intestinal health, and immune response of nursery pigs. J. Anim. Sci. 2009, 87, 2614-2624. [CrossRef] [PubMed]

23. Han, G.Q.; Xiang, Z.T.; Yu, B.; Chen, D.W.; Qi, H.W.; Mao, X.B.; Chen, H.; Mao, Q.; Huang, Z.Q. Effects of different starch sources on Bacillus spp. in intestinal tract and expression of intestinal development related genes of weanling piglets. Mol. Biol. Rep. 2012, 39, 1869-1876. [CrossRef] [PubMed]

24. Fierer, N.; Jackson, J.A.; Vilgalys, R.; Jackson, R.B. Assessment of soil microbial community structure by use of taxon-specific quantitative PCR assays. Appl. Environ. Microbiol. 2005, 71, 4117-4120. [CrossRef] [PubMed]

25. Che, L.; Chen, H.; Yu, B.; He, J.; Zheng, P.; Mao, X.; Yu, J.; Huang, Z.; Chen, D. Long-term intake of pea fiber affects colonic barrier function, bacterial and transcriptional profile in pig model. Nutr. Cancer 2014, 66, 388-399. [CrossRef] [PubMed]

26. Takahashi, S.; Yoshida, Y.; Nakanishi, N.; Takamitsu, T.; Kazunari, U. Quantitative real-time PCR monitoring of Escherichia coli and Clostridium perfringens with oral administration of Lactobacillus plantarum strain Lq80 to weaning piglets. J. Anim. Sci. 2008, 79, 737-744. [CrossRef]

27. Castillo, M.; Martin-Orue, S.M.; Manzanilla, E.G.; Badiola, I.; Martin, M.; Gasa, J. Quantification of total bacteria, enterobacteria and lactobacilli populations in pig digesta by real-time PCR. Vet. Microbiol. 2006, 114, 165-170. [CrossRef] [PubMed]

28. Furet, J.P.; Firmesse, O.; Gourmelon, M.; Bridonneau, C.; Tap, J.; Mondot, S.; Dore, J.; Corthier, G. Comparative assessment of human and farm animal faecal microbiota using real-time quantitative PCR. FEMS Microbiol. Ecol. 2009, 68, 351-362. [CrossRef]

29. Xun, W.; Shi, L.; Zhou, H.; Hou, G.; Cao, T.; Zhao, C. Effects of curcumin on growth performance, jejunal mucosal membrane integrity, morphology and immune status in weaned piglets challenged with enterotoxigenic Escherichia coli. Int. Immunopharmacol. 2015, 27, 46-52. [CrossRef]

30. Zhou, X.; Zhang, Y.; Wu, X.; Wan, D.; Yin, Y. Effects of Dietary Serine Supplementation on Intestinal Integrity, Inflammation and Oxidative Status in Early-Weaned Piglets. Cell. Physiol. Biochem. 2018, 48, 993-1002. [CrossRef]

31. Zhu, Y.H.; Li, X.Q.; Zhang, W.; Zhou, D.; Liu, H.Y.; Wang, J.F. Dose-dependent effects of Lactobacillus rhamnosus on serum interleukin-17 production and intestinal T-cell responses in pigs challenged with Escherichia coli. Appl. Environ. Microbiol. 2014, 80, 1787-1798. [CrossRef]

32. Souza, F.; Malheiros, E.; Carneiro, P. Positioning and number of nutritional levels in dose-response trials to estimate the optimal-level and the adjustment of the models. Ciência Rural 2014, 44, 1204-1209. [CrossRef]

33. Blikslager, A.T.; Moeser, A.J.; Gookin, J.L.; Jones, S.L.; Odle, J. Restoration of barrier function in injured intestinal mucosa. Physiol. Rev. 2007, 87, 545-564. [CrossRef] [PubMed]

34. Wijtten, P.J.; van der Meulen, J.; Verstegen, M.W. Intestinal barrier function and absorption in pigs after weaning: A review. Br. J. Nutr. 2011, 105, 967-981. [CrossRef] [PubMed]

35. Song, W.B.; Lv, Y.H.; Zhang, Z.S.; Li, Y.N.; Xiao, L.P.; Yu, X.P.; Wang, Y.Y.; Ji, H.L.; Ma, L. Soluble intercellular adhesion molecule-1, D-lactate and diamine oxidase in patients with inflammatory bowel disease. World J. Gastroenterol. 2009, 15, 3916-3919. [CrossRef]

36. Guo, Y.Y.; Liu, M.L.; He, X.D.; Jiang, C.Q.; Liu, R.L. Functional changes of intestinal mucosal barrier in surgically critical patients. World J. Emerg. Med. 2010, 1, 205-208. 
37. Zhao, Y.; Qin, G.; Sun, Z.; Che, D.; Bao, N.; Zhang, X. Effects of soybean agglutinin on intestinal barrier permeability and tight junction protein expression in weaned piglets. Int. J. Mol. Sci. 2011, 12, 8502-8512. [CrossRef]

38. Rong, Y.; Lu, Z.; Zhang, H.; Zhang, L.; Song, D.; Wang, Y. Effects of casein glycomacropeptide supplementation on growth performance, intestinal morphology, intestinal barrier permeability and inflammatory responses in Escherichia coli K88 challenged piglets. Anim. Nutr. 2015, 1, 54-59. [CrossRef]

39. Fukudome, I.; Kobayashi, M.; Dabanaka, K.; Maeda, H.; Okamoto, K.; Okabayashi, T.; Baba, R.; Kumagai, N.; Oba, K.; Fujita, M.; et al. Diamine oxidase as a marker of intestinal mucosal injury and the effect of soluble dietary fiber on gastrointestinal tract toxicity after intravenous 5-fluorouracil treatment in rats. Med. Mol. Morphol. 2014, 47, 100-107. [CrossRef]

40. Smith, F.; Clark, J.E.; Overman, B.L.; Tozel, C.C.; Huang, J.H.; Rivier, J.E.; Blikslager, A.T.; Moeser, A.J. Early weaning stress impairs development of mucosal barrier function in the porcine intestine. Am. J. Physiol. Gastrointest. Liver Physiol. 2010, 298, 352-363. [CrossRef]

41. Murray, M.J.; Barbose, J.J.; Cobb, C.F. Serum D(-)-lactate levels as a predictor of acute intestinal ischemia in a rat model. J. Surg. Res. 1993, 54, 507-509. [CrossRef]

42. Ruh, J.; Vogel, F.; Schmidt, E.; Werner, M.; Klar, E.; Secchi, A.; Gebhard, M.M.; Glaser, F.; Herfarth, C. Effects of hydrogen peroxide scavenger Catalase on villous microcirculation in the rat small intestine in a model of inflammatory bowel disease. Microvasc. Res. 2000, 59, 329-337. [CrossRef] [PubMed]

43. Chen, H.L.; Cheng, H.C.; Wu, W.T.; Liu, Y.J.; Liu, S.Y. Supplementation of konjac glucomannan into a low-fiber Chinese diet promoted bowel movement and improved colonic ecology in constipated adults: A placebo-controlled, diet-controlled trial. J. Am. Coll. Nutr. 2008, 27, 102-108. [CrossRef] [PubMed]

44. Zhao, L.; Luo, L.; Jia, W.; Xiao, J.; Huang, G.; Tian, G.; Li, J.; Xiao, Y. Serum diamine oxidase as a hemorrhagic shock biomarker in a rabbit model. PLoS ONE 2014, 9, e102285. [CrossRef] [PubMed]

45. Dibner, J.J.; Buttin, P. Use of organic acids as a model to study the impact of gut microflora on nutrition and metabolism. J. Appl. Poult. Res. 2002, 11, 453-463. [CrossRef]

46. Leser, T.D.; Amenuvor, J.Z.; Jensen, T.K.; Lindecrona, R.H.; Boye, M.; Moller, K. Culture-Independent Analysis of Gut Bacteria: The Pig Gastrointestinal Tract Microbiota Revisited. Appl. Environ. Microb. 2002, 68, 673-690. [CrossRef] [PubMed]

47. Bixia, L.I.; Zhao, F.; Zhao, W. Effects of Different Dietary Crude Fiber Levels on the Growth Performance and Slaughter Performance of Finishing Pigs. J. Domest. Anim. Ecol. 1977, 40, 288-295.

48. Mikkelsen, L.L. Effects of physical properties of feed on microbial ecology and survival of Salmonella enterica serovar Typhimurium in the pig gastrointestinal tract. Appl. Environ. Microbiol. 2004, 70, 3485-3492. [CrossRef]

49. Gardiner, G.E.; Campbell, A.J.; Doherty, J.V.; Pierce, E.; Lynch, P.B.; Leonard, F.C.; Stanton, C.; Ross, R.P.; Lawlor, P.G. Effect of Ascophyllum nodosum extract on growth performance, digestibility, carcass characteristics and selected intestinal microflora populations of grower-finisher pigs. Anim. Feed Sci. Technol. 2008, 141, 259-273. [CrossRef]

50. Demeckova, V.; Tsourgiannis, C.A. Beneficial changes of Lactobacilli, coliforms and E. coli numbers in the faeces of farrowing primiparous sows, achieved by fermented liquid feed, positively affect subsequent neonatal colonisation. Antonie Van Leeuwenhoek 2003, 95, 373-385.

51. Drew, M.D.; Van Kessel, A.G.; Estrada, A.E.; Ekpe, E.D.; Zijlstra, R.T. Effect of dietary cereal on intestinal bacterial populations in weaned pigs. Can. J. Anim. Sci. 2002, 82, 607-609. [CrossRef]

52. Nielsen, T.S.; Laerke, H.N.; Theil, P.K.; Sorensen, J.F.; Saarinen, M.; Forssten, S.; Knudsen, K.E. Diets high in resistant starch and arabinoxylan modulate digestion processes and SCFA pool size in the large intestine and faecal microbial composition in pigs. Br. J. Nutr. 2014, 112, 1837-1849. [CrossRef] [PubMed]

53. Gregoire, R.; Yeung, K.S.; Stadler, J.; Stern, H.S.; Kashtan, H.; Neil, G.; Bruce, W.R. Effect of high-fat and low-fiber meals on the cell proliferation activity of colorectal mucosa. Nutr. Cancer 1991, 15, 21-26. [CrossRef] [PubMed]

54. Jin, L.; Reynolds, L.P.; Redmer, D.A.; Caton, J.S.; Crenshaw, J.D. Effects of dietary fiber on intestinal growth, cell proliferation, and morphology in growing pigs. J. Anim. Sci. 1994, 72, 2270-2278. [CrossRef] [PubMed]

(C) 2019 by the authors. Licensee MDPI, Basel, Switzerland. This article is an open access article distributed under the terms and conditions of the Creative Commons Attribution (CC BY) license (http://creativecommons.org/licenses/by/4.0/). 